\title{
The effects of nitrous oxide on vitamin B12 and homocysteine levels in methyltetrahydrofolate reductase gene mutation
}

\author{
Hakimoglu $\mathrm{S}^{1}$, Hanci $\mathrm{V}^{1}$, Hakimoglu $\mathrm{Y}^{2}$, Cicek $\mathrm{S}^{3}$, Yurtlu $\mathrm{S}^{1}$, Okyay RD ${ }^{1}$, Ayoglu $\mathrm{H}^{1}$, Can $\mathrm{M}^{2}$, \\ Mungan $\mathrm{G}^{2}$, Dursun $\mathrm{A}^{3}$, Turan $\mathrm{IO}^{1}$
}

Department of Anesthesiology and Reanimation, Zonguldak Karaelmas University, School of Medicine, Zonguldak, Turkey. vhanci@gmail.com

\begin{abstract}
Background: We aimed to investigate the effects of nitrous oxide on plasma total homocysteine and vitamin B12 levels in patients with or without methyltetrahydrofolate reductase (MTHRF) gene mutation.

Methods: After obtaining the ethics committee approval and written informed consents of patients, 93 patients between 18-70 years of age scheduled for surgery anticipated to last 1-4 hours were enrolled in the study. Patients with contraindications for nitrous oxide use were excluded. Preoperatively, blood samples were obtained from all patients for the determination of MTHFR gene mutation. Anesthesia induction was achieved with $3 \mathrm{mg} . \mathrm{kg}^{-1}$ of propofol and $1 \mu \mathrm{g} . \mathrm{kg}^{-1}$ of fentanyl. Anesthesia maintenance was performed with sevoflurane and with a carrier gas composed of $40 \% \mathrm{O}_{2}$ and $60 \% \mathrm{~N}_{2} \mathrm{O}$. Venous blood samples were obtained after venous canulation, and 24 hours after extubation for the analysis of plasma total homocysteine, vitamin B12 levels. Results: Eighty-one patients were included in the study. Postoperative vitamin B12 levels were found to be significantly lower when compared with their preoperative levels $(p<0.05)$. It was found that MTHRF gene polymorphism had no significant effect on postoperative plasma total homocysteine and serum vitamin B12 levels $(p>0.05)$. Postoperative plasma total homocysteine levels were found to be significantly different between patients with operation times under and over 3 hours $(p=0.028)$.

Conclusions: We conclude that MTHRF gene polymorphism had no significant effects on postoperative plasma total homocysteine levels. However, we found that homocysteine levels might rise in patients who received general anesthesia with nitrous oxide for longer than 3 hours (Tab. 7, Ref. 26). Full Text in PDF www.elis.sk. Key words: nitrous oxide, general anesthesia, homocysteine, vitamin B12, methyltetrahydrofolate reductase.
\end{abstract}

Functioning as an important enzyme in folic acid metabolism, 5,10-methyltetrahydrofolate reductase (MTHFR) is a flavoprotein with 656 amino acids. The human MTHFR gene is located on the short arm of chromosome 1 at position 36.3 (1). MTHRF gene mutation is an autosomal recessive disease (2). The decrease in the MTHFR enzyme due to this mutation may increase plasma total homocysteine (tHcy) levels and risk of thromboembolic events and myocardial infarctions (3).

Nitrous oxide is the only inorganic substance used commonly in anesthesia owing to its strong analgesic properties (4). After initiating general anesthesia with nitrous oxide, an elevation has been shown in plasma total homocysteine levels $(3,5)$, which is reported to increase the risk of serious postoperative complications such as thromboembolic events and myocardial infarctions (6). Despite this, only a few studies have investigated the effects

${ }^{1}$ Department of Anesthesiology and Reanimation, Zonguldak Karaelmas University, School of Medicine, Zonguldak, Turkey, ${ }^{2}$ Department of Biochemistry, Zonguldak Karaelmas University, School of Medicine, Zonguldak, Turkey, and ${ }^{3}$ Department of Medical Genetics Zonguldak Karaelmas University, School of Medicine, Zonguldak, Turkey

Address for correspondence: V. Hanci, MD, Tepebasi Mahallesi, Yapkent sokak, Kale Sitesi A13 Blok, Daire:10, Zonguldak, Turkey. Phone: +90.505 .680 .60 .53$

Financial support: This work was supported by Karaelmas University Scientific Research Projects Unit. of nitrous oxide used in anesthesia maintenance on MTHFR gene mutation patients (2).

A major part of anesthesia practice comprises of ambulatory patients with a short operation time. In this prospective double blind study using a mendelian randomization approach, we have investigated the effects of nitrous oxide on the plasma total homocysteine and serum vitamin B12 levels of patients with and without MTHFR gene mutation who were scheduled for surgeries of 1-4 hours duration.

\section{Material and method}

Our study was conducted in the Anesthesia and Reanimation Department of Zonguldak Karaelmas University's Faculty of Medicine Hospital between July 2008 and July 2009 after obtaining ethics committee approval. Ninety-three ambulatory adult patients aged between 18-70 who received general anesthesia for 1-4 hours were enrolled in the study after reading the 'Informed Voluntary Consent Form' and providing their written consent.

Patients with heart and kidney disease (creatinine $>1.3 \mathrm{mg} \cdot \mathrm{dl}^{-1}$ ), renal insufficiency, vitamin B12 deficiency $(<150 \mathrm{pg} / \mathrm{ml})$, serum folic acid deficiency $\left(<3 \mathrm{ng} \cdot \mathrm{ml}^{-1}\right)$, severe anemia $\left(<8\right.$ g. $\left.\mathrm{dl}^{-1}\right)$, and pregnant and lactating patients were excluded from the study. In addition, patients with contraindications for nitrous oxide use who were suffering from pneumothorax, mechanical bowel obstruction, 
middle ear blockage, laparoscopic surgery, and high intracranial pressure were also excluded. Exclusion criteria also included vitamin B12 or folic acid use prior to the operation.

All patients received premedication with $0.07 \mathrm{mg} . \mathrm{kg}^{-1}$ intramuscular midazolam one hour before the operation.

Vascular access was obtained in all patients by using 18 Gauche cannula on the non-dominant hand. Prior to induction, patients received fluid replacement with $7 \mathrm{ml} / \mathrm{kg}$ ringer lactate and preoxygenation for 3 minutes with 10 L.min ${ }^{-1} 100 \%$ oxygen.

The monitoring of patients in the operating room was undertaken with ADU (Datex-Ohmeda ${ }^{\circledR} \mathrm{S} / 5$ Anesthesia Monitor, USA) and electrocardiograph of 5 derivations (ECG, DII), peripheral oxygen saturation $\left(\mathrm{SpO}_{2}\right)$ and noninvasive arterial blood pressure.

Anesthesia induction was conducted with $3 \mathrm{mg} / \mathrm{kg}$ propofol (Pofol ${ }^{\circledR}$, Fresenius Kabi AB, Sweden) and $1 \mu \mathrm{g} / \mathrm{kg}$ fentanyl (Fentanyl Citrate ${ }^{\circledR}$ Hospira Inc. USA). For muscle relaxation, $0,1 \mathrm{mg} /$ $\mathrm{kg}$ Vecuronium (Norcuron ${ }^{\circledR}$ N.V. Organon, Holland) was used, followed by intubation $3 \mathrm{~min}$ later. After the intubation fresh gas flow was set to $4 \mathrm{~L} \cdot \mathrm{min}^{-1}$ for $10 \mathrm{~min}$, thereafter it was reduced to $2 \mathrm{~L} \cdot \mathrm{min}^{-1}$ Anesthesia was maintained with 1-2 MAC sevoflurane (Sevorane Likit $^{\circledR}$ Abbott, USA) within $40 \% \mathrm{O}_{2} 60 \% \mathrm{~N}_{2} \mathrm{O}$ mixture. Ventilation was maintained with a tidal volume (TV) setting at $8 \mathrm{ml} \cdot \mathrm{kg}^{-1}$, and a respiratory frequency to keep Et $\mathrm{CO}_{2}$ between $35-40 \mathrm{mmHg}$. The $\mathrm{FiO}_{2}$ value was maintained between 30-35\%. Anesthetics were stopped at the onset of final sutures of operation and the patients were ventilated with $100 \% \mathrm{O}_{2}$. The effects of muscle relaxants were antagonized with 0.05 mg. $\mathrm{kg}^{-1}$ neostigmine (Neostigmin Ampul $^{\mathbb{B}}$ Adeka, Turkey) and $0.01 \mathrm{mg} \cdot \mathrm{kg}^{-1}$ atropine (Atropin Sülfat ${ }^{\mathbb{B}} 1$ $\mathrm{ml}$ amp, Biofarma, Turkey). Once adequate tidal volume and preventive airway reflexes returned, patients were extubated. Postoperative pain management was obtained by using $1 \mathrm{mg} . \mathrm{kg}^{-1}$ tramadol (Ultramex ${ }^{\circledR}$, Adeka, Turkey) 15 mins before the end of operation.

After obtaining vascular access, $2 \mathrm{ml}$ venous blood samples were drawn from all patients into 2 EDTA tubes. In addition, venous blood samples required for the analysis of patients' plasma total homocysteine, serum vitamin B12 levels were drawn at 24 hours after extubation.

All patients were grouped according to MTHFR gene polymorphism. The groups were compared with respect to their demographic data, operation duration, preoperative BUN, creatinine, albumin, folic acid, vitamin B12 and plasma total homocysteine levels. In addition, patient were grouped according to their operation duration as under or over 3 hours, and plasma total homocysteine levels were compared again.

\section{Genetic analyses}

In order to determine gene polymorphism, the blood samples drawn into EDTA tubes were frozen and stored at $-80{ }^{\circ} \mathrm{C}$ until DNA and genetic analyses were performed. The DNA isolation was done by using NucleoSpin ${ }^{\circledR}$ Blood (Card. no: 740 951.250) DNA isolation kit in line with manufacturer's recommendations. Consequently, $200 \mu 1$ DNA was obtained in approximately 40-60 ng. $\mu 1^{-1}$ concentration. The DNA obtained was examined for C677T and A1298C mutations by using Dr. Zeydanlı Real-Time MTH-
FR analysis test (Card. No: DZ677/DZ1298) and following the manufacturer's protocol. Four mastermixes were studied for each patient, such as 677 patented or 1298 Normal and 677 or $1298 \mathrm{Mu}-$ tant. The kit provides ready-to-use chemicals prepared specifically for 5' nuclear polymerase chain reaction (PCR) used in patented single nucleotide polymorphism (SNP) analysis. The test kit is prepared for MTHFR C677T / A1298C sequence specific primers and probes. $20.5 \mu 1$ ready-to-use mutant and normal mastermix was stored in $0.2 \mathrm{ml}$ thermowell optical PCR tubes or strips. In each normal and mutant mastermix tube was $0.3 \mu 1$ Hot Start Taq DNA Polymerase and $4.5 \mu 1$ DNA added. They were completely mixed with straws. PCR was studied by using the program recommended by the manufacturer. Data obtained in the study were analyzed by using STRATAGENE ${ }^{\circledR}$, MxPro ${ }^{\mathrm{TM}}$ QPCR Software Instruction Manual, Mx3000P'M QPCR Systems, Software Version 3.00. Analysed results were compared with samples including the standard amplification distributions given below, and then assessed.

\section{Biochemical analyses}

Samples drawn into gel biochemical tubes for serum folic acid and vitamin B12 measurement were centrifuged at $5000 \mathrm{rpm}$ for 5 minutes and the serums were isolated. Samples drawn into EDTA hemogram tubes for homocysteine measurement were also centrifuged at $5000 \mathrm{rpm}$ for $5 \mathrm{mins}$ to isolate their plasma. All samples were frozen and stored at $-80{ }^{\circ} \mathrm{C}$ until the end of study. Serum folic acid and vitamin B12 were measured by using IMMULITE $^{\circledR}$ 2000 (Siemens, Germany) with the chemiluminescence method. In line with the competitive immunochemical principle, folic acid was measured as pg. $\mathrm{ml}^{-1}$ and vitamin B12 as ng. $\mathrm{ml}^{-1}$. Plasma total homocysteine values were measured as $\mu$ mol. $L^{-1}$ by using the ZinMass ${ }^{\circledR}$ Homocysteine LC-MS/MS analysis kit (ZIVAK, Turkey) high pressure fluid chromotography (HPLC) and using a fluorescent detector with the isocratic method. BUN, creatinine and albumin were measured as mg/dl by using ADVIA 2400 (Siemens, Germany ) autoanalyzer.

\section{Statistics}

\section{Sample size determination}

Our primary endpoint was the postoperative plasma total homocysteine concentrations in healthy individuals with the MTHFR 677 and 1298 genotypes. Sample size estimation was based on a similar study conducted by Nagele et al (2). In order to detect a 20 $\%$ change in postoperative plasma total homocysteine concentrations [8.2 (6.9-10.1) in Nagele P.'s study)], with an $\alpha$ error of 0.05 and a power of $80 \%$, we calculated that sample size should be at least 22 patients per group (Homozygous and Wild-type or Heterozygous Patients). The sample size estimation was performed using Power Calculator (Department of Statistics, University of California, Los Angeles; http://www.stat.ubc.ca/_rollin/stats/ssize).

\section{Statistical analyses}

Statistical analyses were done on SPSS (version 13.0). The Kolmogorov-Smirnov test was used to evaluate whether numeri- 
Tab. 1. The distribution of MTHFR gene mutations in patients.

\begin{tabular}{|c|c|c|c|c|c|c|c|c|}
\hline \multirow{3}{*}{ MTHFR 677 Genotype } & \multicolumn{8}{|c|}{ MTHFR 1298 Genotype } \\
\hline & \multicolumn{2}{|c|}{$\begin{array}{c}\text { Normal } \\
\text { AA }\end{array}$} & \multicolumn{2}{|c|}{$\begin{array}{c}\text { Heterozygous } \\
\mathrm{AC}\end{array}$} & \multicolumn{2}{|c|}{$\begin{array}{c}\text { Homozygous } \\
\text { CC }\end{array}$} & \multicolumn{2}{|c|}{ Total } \\
\hline & $\mathrm{N}$ & $\%$ & $\mathrm{~N}$ & $\%$ & $\mathrm{~N}$ & $\%$ & $\mathrm{n}$ & $\%$ \\
\hline Normal CC & 12 & 14.8 & 13 & 16 & 12 & 14.8 & 37 & 45.6 \\
\hline Heterozygous CT & 14 & 17.3 & 17 & 21 & 0 & 0 & 31 & 38.3 \\
\hline Homozygous TT & 13 & 16 & 0 & 0 & 0 & 0 & 13 & 16 \\
\hline Total & 39 & 48.1 & 30 & 37 & 12 & 14.8 & 81 & 100 \\
\hline
\end{tabular}

MTHFR 677 Genotype: C677C ; normal, C677T; Heterozygous, T677T; Homozygous,

MTHFR 1298 Genotype: A1298A; normal, A1298C; Heterozygous, C1298C; Homozygous

Tab. 2. Preoperative BUN, creatinine and albumin levels in groups (mean \pm SD).

\begin{tabular}{lcccccc}
\hline $\begin{array}{l}\text { Mutation } \\
677 / 1298\end{array}$ & $\begin{array}{c}\text { BUN } \\
(\mathrm{mg} / \mathrm{dl})\end{array}$ & $\mathrm{p}$ & $\begin{array}{c}\text { Creatinine } \\
(\mathrm{mg} / \mathrm{dl})\end{array}$ & $\mathrm{p}$ & $\begin{array}{c}\text { Albumin } \\
(\mathrm{mg} / \mathrm{dl})\end{array}$ & $\mathrm{p}$ \\
\hline $\mathrm{CC} / \mathrm{AAn}=12$ & $32.11 \pm 6.72$ & $0.73 \pm 0.20$ & & $4.11 \pm 0.44$ & \\
CT/AC $\mathrm{n}=17$ & $30.01 \pm 9.71$ & $0.78 \pm 0.16$ & & $4.08 \pm 0.26$ & \\
$\mathrm{CT} / \mathrm{AA} \mathrm{n}=14$ & $26.66 \pm 11.61$ & 0,274 & $0.76 \pm 0.16$ & 0,351 & $4.05 \pm 0.51$ & 0.790 \\
TT/AA n $=13$ & $27.18 \pm 12.38$ & $0.70 \pm 0.13$ & & $4.29 \pm 0.40$ & \\
CC/AC $\mathrm{n}=13$ & $32.07 \pm 9.34$ & $0.74 \pm 0.19$ & & $4.19 \pm 0.42$ & \\
$\mathrm{CC} / \mathrm{CC} \mathrm{n}=12$ & $27.76 \pm 9.91$ & $0.69 \pm 0.21$ & & $4.01 \pm 0.20$ & \\
\hline
\end{tabular}

MTHFR 677 Genotype: C677C ; normal, C677T; Heterozygous, T677T; Homozygous,

MTHFR 1298 Genotype: A1298A; normal, A1298C; Heterozygous, C1298C; Homozygous

cal variables had normal distribution. The Kruskal-Wallis test was used to find the difference between methyltetrahydrofolate reductase gene polymorphism groups with respect to age, height, weight, operation duration, BUN, albumin, and creatinine. The gender distribution of groups was examined with the Chi-Square test. For within-group assessments, Wilcoxon test was used for the preoperative and postoperative vitamin B12 and homocyste- ine values. Analysis of variance was utilized in repeated measurements to identify the difference between the groups' preoperative and postoperative vitamin B12 and homocysteine values. When patients were grouped according to operation duration, MannWhitney U test was used for analyses under and over 3 hours. The results were considered in the $95 \%$ confidence interval, and $\mathrm{p}<0.05$ was accepted significant.

\section{Results}

A total of 93 patients were enrolled in the study. Eight of these patients were excluded as their vitamin B12 levels were under 150 pg.ml ${ }^{-1}$, and another 4 were also excluded because of their folic acid levels were under $3 \mathrm{ng} \cdot \mathrm{ml}^{-1}$. Following exclusion, data from 81 patients were analyzed.

The mean age of these 81 participants was $41.09 \pm 13.59$. Fortynine $(60.5 \%)$ patients were females and $32(39.5 \%)$ were males.

When MTHFR polymorphisms were examined, we found that 12 (14.8\%) patients didn't have polymorphism. 677 CT/1298 AC mutation was identified in 17 (21\%) of the patients, 677 TT/1298

Tab. 3. Age, height, weight and operation duration values in groups (mean \pm SD).

\begin{tabular}{|c|c|c|c|c|c|c|c|c|}
\hline Mutation $677 / 1298$ & Age (years) & $\mathrm{p}$ & Height (kg) & $\mathrm{p}$ & Weight $(\mathrm{cm})$ & $\mathrm{p}$ & Operation duration (min) & $\mathrm{p}$ \\
\hline$\overline{\mathrm{CC} / \mathrm{AA} \mathrm{n}=12}$ & $48.91 \pm 13.46$ & \multirow{6}{*}{0.274} & $79.50 \pm 21.86$ & \multirow{6}{*}{0.351} & $167.25 \pm 9.95$ & \multirow{6}{*}{0.790} & $112.50 \pm 66.62$ & \multirow{6}{*}{0.908} \\
\hline $\mathrm{CT} / \mathrm{AC} \mathrm{n}=17$ & $44.11 \pm 14.34$ & & $68.05 \pm 11.22$ & & $166.11 \pm 6.06$ & & $105.88 \pm 57.23$ & \\
\hline $\mathrm{TT} / \mathrm{AA} \mathrm{n}=13$ & $38.84 \pm 12.62$ & & $71.07 \pm 10.63$ & & $163.69 \pm 6.47$ & & $110.76 \pm 56.63$ & \\
\hline $\mathrm{CT} / \mathrm{AA} \mathrm{n}=14$ & $39.14 \pm 15.06$ & & $74.07 \pm 13.37$ & & $167.71 \pm 8.78$ & & $87.85 \pm 34.23$ & \\
\hline $\mathrm{CC} / \mathrm{AC} \mathrm{n}=13$ & $38.00 \pm 13.47$ & & $66.92 \pm 14.86$ & & $165.00 \pm 6.70$ & & $101.53 \pm 56.83$ & \\
\hline $\mathrm{CC} / \mathrm{CC} \mathrm{n}=12$ & $37.08 \pm 10.09$ & & $74.83 \pm 12.38$ & & $166.16 \pm 6.56$ & & $150 \pm 35.03$ & \\
\hline
\end{tabular}

MTHFR 677 Genotype: C677C ; normal, C677T; Heterozygous, T677T; Homozygous,

MTHFR 1298 Genotype: A1298A; normal, A1298C; Heterozygous, C1298C; Homozygous

Tab. 4. Preoperative values of All homozygous patients and other patients' (mean \pm SD).

\begin{tabular}{|c|c|c|c|c|}
\hline & $\begin{array}{l}\text { All patients } \\
\quad(\mathrm{n}=81)\end{array}$ & $\begin{array}{l}\text { Homozygous patients } \\
\qquad(\mathrm{n}=25)\end{array}$ & $\begin{array}{l}\text { Heterozygous or Normal patients } \\
\qquad(\mathrm{n}=56)\end{array}$ & $\mathrm{p}$ \\
\hline$\overline{\mathrm{BUN}}(\mathrm{mg} / \mathrm{dl})$ & $29.29 \pm 10.07$ & $27.46 \pm 11.03$ & $30.10 \pm 9.60$ & 0.242 \\
\hline Creatinine (mg/dl) & $0.74 \pm 0.17$ & $0.69 \pm 0.17$ & $0.76 \pm 0.17$ & 0.187 \\
\hline Albumin (mg/dl) & $4.12 \pm 0.38$ & $4.16 \pm 0.34$ & $4.10 \pm 0.40$ & 0.728 \\
\hline Vitamin B12 (pg/ml) & $305.72 \pm 167.40$ & $285.88 \pm 188.24$ & $314.58 \pm 158.23$ & 0.166 \\
\hline Folic acid (ng/ml) & $9.03 \pm 4.28$ & $7.96 \pm 2.85$ & $9.51 \pm 4.72$ & 0.222 \\
\hline Homosistein $(\mu \mathrm{mol} / \mathrm{L})$ & $13.89 \pm 5.17$ & $14.98 \pm 6.48$ & $13.40 \pm 4.45$ & 0.563 \\
\hline Weight $(\mathrm{cm})$ & $166 \pm 7.36$ & $164.88 \pm 6.50$ & $166.50 \pm 7.72$ & 0.358 \\
\hline Height (kg) & $72.09 \pm 14.46$ & $72.88 \pm 11.42$ & $71.75 \pm 15.71$ & 0.598 \\
\hline Operation duration (min) & $103.70 \pm 51.53$ & $108 \pm 46.63$ & $101.78 \pm 53.87$ & 0.338 \\
\hline
\end{tabular}

MTHFR 677 Genotype: C677C ; normal, C677T; Heterozygous, T677T; Homozygous,

MTHFR 1298 Genotype: A1298A; normal, A1298C; Heterozygous, C1298C; Homozygous 
Tab. 5. Preoperative and Postoperative serum vitamin B12 and plasma total homocysteine values in all patients $(n=81)($ mean \pm SD).

\begin{tabular}{lccc}
\hline & Preoperative & $\begin{array}{c}\text { Posteoperative } \\
(24 \text { th hours })\end{array}$ & $\mathrm{p}$ \\
\hline Vitamin B12 $(\mathrm{pg} / \mathrm{ml})$ & $305,72 \pm 167,40$ & $288,59 \pm 138$ & 0,029 \\
Homocysteine $(\mu \mathrm{mol} / \mathrm{l})$ & $13,89 \pm 5,17$ & $15,06 \pm 11,67$ & 0,323 \\
\hline
\end{tabular}

AA mutation in 13 (16\%), $677 \mathrm{CT} / 1298$ AA mutation in 14 (17.3 \%), $677 \mathrm{CC} / 1298 \mathrm{AC}$ mutation in 13 (16\%), and finally 677 CC/1298 CC mutation in 12 (14.8\%) (Tab. 1).

Patients were grouped according to their MTHFR gene mutations and no difference was found between the preoperative serum BUN, creatinine and albumin values in the groups (Tab. 2). Likewise, a significant difference did not exist between the age, weight, height and operation durations in the groups (Tab. 3). Among the patients, there was no statistical difference between the preoperative age, weight, height, vitamin B12, folic acid, homocysteine values and operation durations of patients who had homozygous mutation in either gene 677 or 1298 and patients with heterozygous mutation in either gene 677 or 1298 or normal patients (Tab. 4).

The preoperative serum vitamin B12 level of all patients was $305.72 \pm 167.40 \mathrm{pg} \cdot \mathrm{ml}^{-1}$, while postoperative serum vitamin B12 level felt to $288.59 \pm 138 \mathrm{pg} . \mathrm{ml}^{-1}$. A significant difference was present between preoperative and postoperative serum vitamin B12 levels of patients $(\mathrm{p}=0.029)$. While patients' mean preoperative plasma total homocysteine value was $13.89 \pm 5.17 \mu$ mol..$^{-1}$, their mean postoperative plasma total homocysteine value was $15.06 \pm 11.67$ $\mu \mathrm{mol} . \mathrm{l}^{-1}$. Despite the increase in plasma total homocysteine levels in the postoperative period, no statistically significant difference was observed between preoperative and postoperative plasma total homocysteine levels (Tab. 5). Based on MTHRF mutations, the groups did not differ significantly with respect to preoperative and postoperative vitamin B12 and homocysteine values (Tab. 6).

When the 81 patients in this study were grouped according to anesthesia duration as under $(n=67,82.7 \%)$ and over 3 hours $(\mathrm{n}=14,17.3 \%)$, no significant difference existed in the age, gender, height and weight of the groups. Postoperative serum homocysteine values were statistically higher in patients whose anesthesia duration was over 3 hours than those whose anesthesia duration was under 3 hours $(p=0.028$ ) (Tab. 7). In the postoperative 24 hours, signs of thromboembolic event or myocardial ischemia were not seen in any patient.

\section{Discussion}

In our study, the serum vitamin B12 levels of our patients were significantly decreased after general anesthesia with nitrous oxide for 1-4 hours. When compared to patients whose operation duration was under 3 hours, the postoperative plasma total homocysteine levels of those whose operation duration was over 3 hours was significantly higher. However, MTHFR gene polymorphism did not have a significant effect on postoperative plasma total homocysteine levels.

Methyltetrahydrofolate reductase deficiency is an autosomal recessive disease with neurological symptoms, premature atherosclerosis, venous and arterial thrombosis. A total of 29 MTHFR mutations have been reported. This mutation has been shown to be associated with severe MTHFR enzyme activity insufficiency. It has been reported that enzyme activity in these mutations is between $0-30 \%$ of control enzyme activity (3). The most important one of these mutations is $\mathrm{C677T}$. In recent cases of severe MTHFR insufficiency, it has been shown to accompany $677 \mathrm{C}>\mathrm{T}$ variant in cis configuration (7). The second most common polymorphism is a 1298

Tab. 7. Preoperative and postoperative serum vitamin B12, and plasma total homocysteine changes according to the operation duration (mean \pm SD).

\begin{tabular}{lccc}
\hline & $\begin{array}{c}<3 \text { hours } \\
(\mathrm{n}=67)\end{array}$ & $\begin{array}{c}>3 \text { hours } \\
(\mathrm{n}=14)\end{array}$ & $\mathrm{p}$ \\
\hline $\begin{array}{l}\text { Age } \\
\text { (Years) }\end{array}$ & $41.52 \pm 12.64$ & $39.07 \pm 17.87$ & 0.516 \\
$\begin{array}{l}\text { Height } \\
(\mathrm{kg})\end{array}$ & $73.11 \pm 12.56$ & $68.28 \pm 21.30$ & 0.061 \\
$\begin{array}{l}\text { Weight } \\
(\mathrm{cm})\end{array}$ & $166.5 \pm 7.61$ & $163.29 \pm 5.45$ & 0.223 \\
$\begin{array}{l}\text { Gender } \\
\text { (Female/Male) }\end{array}$ & $40 / 27$ & $9 / 5$ & 0.498 \\
$\begin{array}{l}\text { Operation duration } \\
\text { (time) }\end{array}$ & $84.17 \pm 29.65$ & $197.14 \pm 2.26$ & $<0.001$ \\
$\begin{array}{l}\text { Preoperative Vitamin B12 } \\
\text { (pg/ml) }\end{array}$ & $314.92 \pm 177.50$ & $261.71 \pm 99.83$ & 0.385 \\
$\begin{array}{l}\text { Postoperative Vitamin B12 } \\
(\text { ng/ml) }\end{array}$ & $297.02 \pm 144.99$ & $248.21 \pm 92.22$ & 0.214 \\
$\begin{array}{l}\text { Preoperative homocysteine } \\
(\mu \mathrm{mol} / \mathrm{L})\end{array}$ & $13.32 \pm 4.49$ & $16.58 \pm 7.24$ & 0.082 \\
$\begin{array}{l}\text { Postoperative homocysteine } \\
(\mu \mathrm{mol} / \mathrm{L})\end{array}$ & $14.18 \pm 11.96$ & $19.27 \pm 9.44 *$ & 0.028 \\
\hline
\end{tabular}

Tab. 6. Preoperative and postoperative plasma total homocysteine and serum vitamin B12 level changes according to the mutation groups $($ mean \pm SD).

\begin{tabular}{|c|c|c|c|c|c|c|}
\hline \multirow{2}{*}{ Mutation $677 / 1298$} & \multicolumn{3}{|c|}{ Homocysteine $(\mu \mathrm{mol} / \mathrm{L})$} & \multicolumn{3}{|c|}{ Vitamin B12 (pg/dl) } \\
\hline & Preoperative & Postoperative $(24 \mathrm{~h})$ & $\mathrm{p}$ & Preoperative & Postoperative (24 h) & $\mathrm{p}$ \\
\hline$\overline{\mathrm{CC} / \mathrm{AA} \mathrm{n}=12}$ & $13.08 \pm 3.89$ & $13.32 \pm 6.98$ & 0.556 & $333.16 \pm 153.84$ & $302.83 \pm 122.47$ & 0.091 \\
\hline $\mathrm{CT} / \mathrm{AC} \mathrm{n}=17$ & $13.25 \pm 2.89$ & $12.66 \pm 4.47$ & 0.518 & $377.94 \pm 223.38$ & $355.41 \pm 197.94$ & 0.298 \\
\hline TT/AA $n=13$ & $16.53 \pm 7.41$ & $19.70 \pm 12.43$ & 0.552 & $287.61 \pm 145.25$ & $257.46 \pm 93.96$ & 0.133 \\
\hline $\mathrm{CT} / \mathrm{AA} \mathrm{n}=14$ & $13.30 \pm 5.08$ & $14.63 \pm 7.28$ & 0.126 & $284.00 \pm 232.99$ & $276.50 \pm 183.58$ & 0.965 \\
\hline $\mathrm{CC} / \mathrm{AC} \mathrm{n}=13$ & $13.24 \pm 7.08$ & $11.50 \pm 5.67$ & 0.154 & $270.76 \pm 102.05$ & $257,46 \pm 56,81$ & 0.944 \\
\hline $\mathrm{CC} / \mathrm{CC} \mathrm{n}=12$ & $13.30 \pm 5.08$ & $14.63 \pm 7.28$ & 0.126 & $284.00 \pm 232.99$ & $276,50 \pm 183,58$ & 0.965 \\
\hline Heterozygous or Normal patients $(n=56)$ & $13,40 \pm 4,45$ & $14.08 \pm 12.16$ & 0.673 & $314.58 \pm 158.23$ & $298.41 \pm 136.80$ & 0.082 \\
\hline
\end{tabular}

MTHFR 677 Genotype: C677C ; normal, C677T; Heterozygous, T677T; Homozygous,

MTHFR 1298 Genotype: A1298A; normal, A1298C; Heterozygous, C1298C; Homozygous 
$\mathrm{A}>\mathrm{C}$ metamorphism, and the glutamate in the regulator zone of MTHFR transforms into alanine. This metamorphism decreases enzyme activity, but is not as distinct as C677T allele transformation. $(8,9)$. Previous studies report that MTHFR C677T and A1298C mutations together decrease MTHFR activity by $40-50 \%$, cause hyperhomocysteine, and decrease plasma folic acid levels $(8,9)$.

In Europe, Middle East and Japan, the prevalence of heterozygous mutation of the MTHFR gene is reported to be 30-40\%, while its homozygous mutation is reported to be $10-15 \%(10)$., the prevalence of MTHFR mutation is less than $5 \%$ in America. In Mexico, the homozygous mutation of MTHRF is reported to be $35 \%$, and homozygous mutation is reported to cause $50-60$ $\%$ decrease in enzyme activity (11). Weisberg et al (11) showed that $15-20 \%$ of the general population is heterozygous in at least one MTHFR variant. Different prevalence results have been obtained in studies investigating MTHFR gene mutation prevalence in various diseases in our country $(12,13,14)$. Yilmaz et al (14) showed heterozygous mutation in $44(47.3 \%)$ and homozygous mutation in $6(6.5 \%)$ patients without coronary arterial disease in the MTHFR C677T gene. On the other hand, they showed heterozygous mutation in $32(40.5 \%)$ and homozygous mutation in $7(8.9 \%)$ patients with coronary artery disease in the same gene (14). Dölek et al (13) studied patients with and without history of thrombosis and found homozygous or heterozygous MTHFR A1298C mutation in 170 (63.2\%) of 270 patients with a history of thrombosis and in 64 (56.1\%) of 114 patients without. Homozygous or heterozygous C677T mutation was found in 134 (49.8 $\%$ ) of 270 patients with previous history of thrombosis and in 45 (39.5\%) of 114 patients without history of thrombosis (13).

Our literature survey showed no data about the MTHFR gene mutation prevalence of hospitalized surgery patients. From our patients included in this study, 12 (14.8\%) did not have MTHFR gene polymorphism. $677 \mathrm{CT} / 1298 \mathrm{AC}$ mutation was found in 17 (21\%) patients, 677 TT/1298 AA mutation in 13 (16\%), 677 CT/1298 AA mutation in 14 (17.3\%), 677 CC/1298 AC mutation in $13(16 \%)$ and $677 \mathrm{CC} / 1298 \mathrm{CC}$ mutation in 12 (14.8\%). Seventeen $(21 \%)$ of the 81 patients who were analyzed genetically had combined mutation in 677 and 1298 allele.

S-adenosylmethionine, an active form of methionine, is used as a substrate for methylation in many biochemical reactions. Previous studies have reported that nitrous oxide irreversibly oxidises the cobalt atom of vitamin B12 and this inhibition results in the inhibition of synthetase activity of methionine, which is a cobalamin-dependent enzyme (15). Amos et al (16) have reported megaloblastic changes in 18 of 50 patients following surgeries of at least 2 hours where $\mathrm{N}_{2} \mathrm{O}$ was administered. They also reported a high correlation between megaloblastic changes and $\mathrm{N}_{2} \mathrm{O}$ exposure in patients with serious diseases (16). In a different study by Krajewski et al (17), 95 surgery nurses who had been exposed to $\mathrm{N}_{2} \mathrm{O}$ were compared with 90 healthy subjects without $\mathrm{N}_{2} \mathrm{O}$ exposure. Although no difference was found with respect to hematological parameters and folic acid levels, it was found that vitamin B12 levels were low and plasma total homocysteine levels were high. In a different study by Royston et al (18), $\mathrm{N}_{2} \mathrm{O}$ use was reported to inhibit methionine synthetase activity, and residual methionine synthetase activity was shown to approach approximately zero, 200 minutes after $\mathrm{N}_{2} \mathrm{O}$ administration started. In our study serum vitamin B12 levels measured at postoperative hour 24 were also significantly lower than preoperative serum vitamin B12 levels in patients who were administered nitrous oxide $(\mathrm{p}<0.05)$.

Several studies have shown that $\mathrm{N}_{2} \mathrm{O}$ increases plasma total homocysteine level (19-21). Mynless et al (22) administered 70 $\% \mathrm{~N}_{2} \mathrm{O}$ to 25 patients and compared them with 34 patients who did not receive $\mathrm{N}_{2} \mathrm{O}$. They measured endothelial function and total plasma homocysteine levels at $24 \mathrm{hrs}$ after $\mathrm{N}_{2} \mathrm{O}$ anesthesia. In the nitrous oxide group, endothelial function was significantly disturbed in the postoperative period and plasma total homocysteine levels were significantly increased (22). Plasma total homocysteine increase induced by nitrous oxide has a complex mechanism. Nitrous oxide directly inhibits methionine synthetase reversibly, thus preventing homocysteine from transforming into methionine and increasing the plasma concentration of homocysteine (23).

The effects of nitrous oxide exposure in patients with MTHRF gene mutation and enzyme deficiency is an important topic of study (2). Previous studies have reported abnormalities in folic acid cycle enzymes caused by $\mathrm{N}_{2} \mathrm{O}$ use in patients with MTHFR mutation $(2,3,5,24-26)$ Selzer et al (5) presented the case of a patient who had 5,10-methyltetrahydrofolate reductase deficiency and ended mortally. Selzer et al (5) argued that mortality could be attributed to the togetherness of MTHFR mutation and $\mathrm{N}_{2} \mathrm{O}$-related methionine synthetase enzyme defect.

However, there is only one study that has attempted to determine the effects of MTHFR gene mutation on postoperative plasma total homocysteine levels (2). In this study, Nagele et al (2) studied the effects of two MTHFR gene mutations (677 C > T and $1298 \mathrm{~A}>\mathrm{T}$ ) on postoperative plasma total homocysteine, serum vitamin B12 and folic acid levels among the 140 patients who received $66 \% \mathrm{~N}_{2} \mathrm{O}$ anesthesia for longer than 2 hours. They reported significantly increased postoperative plasma homocysteine levels as compared to preoperative levels. The same study also stressed that postoperative total plasma homocysteine concentrations were significantly higher in homozygous C677T or A1298C MTHFR gene mutation patients than those who did not carry this mutation homozygously. This study found no difference between the plasma folic acid levels of patients grouped according to MTHFR gene mutation. The study also showed that vitamin B12 levels felt in all patients in the postoperative period, though the decrease was higher among homozygous patients (2). The same researchers also showed that plasma total homocysteine concentrations rose from $8.1 \mu \mathrm{mol} . \mathrm{L}^{-1}$ to $14.6 \mu \mathrm{mol} . \mathrm{L}^{-1}$ in patients that were exposed to $\mathrm{N}_{2} \mathrm{O}$ for longer than 4 hours, and that this increase was higher in these patients than in those who were exposed to nitrous oxide for a shorter period of time (2). The authors stressed that the effects of long-term nitrous oxide exposure on plasma total homocysteine levels were independent from MTHFR gene mutation (2).

Although postoperative serum vitamin B12 levels decreased and plasma total homocysteine levels increased in our patients who received nitrous oxide anesthesia for 1-4 hours, we did not find MTHFR C677T and A1298C genes polymorphisms to have a significant effect on postoperative serum vitamin-B12, folic acid and 
total homocysteine levels. As with Nagele's (2) study, the plasma total homocysteine levels of our patients who received anesthesia with nitrous oxide for more than three hours were significantly increased. It can be concluded that nitrous oxide exposure time emerges as a factor which affects plasma total homocysteine levels independently of MTHRF gene mutation.

The results of our study regarding the effect of MTHFR mutation on postoperative homocystein levels are in controversy with the results of Nagele et al in that MTHFR mutations do not effect postoperative homocystein levels. However we must note several points: first, we have excluded patients whose preoperative Vit B12 and folate levels were lower than predetermined tresholds for each, since it would have implications on homocystein levels. Second, preoperative plasma homocystein levels were not statistically different in our present study, however they were found to be different in the previous study (2). Third, sample drawing times between the two studies are different, we took the samples at the 24th hour after anesthesia, Nagele et al took samples at the $2 \mathrm{nd} \mathrm{hr}$ of anesthesia and end of the surgery which depend on surgical time and vary greatly with operational duration. Furthermore, some of the operations in Nagele's study seem to last only half an hour as they gave the duration of surgery of $2.2 \mathrm{~h}(0.5-7.4)$ (min-max). We had no operation lasting less than 1 hour. Therefore in our opinion MTHFR mutations are not correlated to postoperative homocysteine levels since have swept away out some methodological disorders.

The most important limitation of our study is the small number of patients due to high costs of the tests, which may have been a factor that affected our results.

In conclusion, in our opinion MTHFR gene mutation does not increase plasma homocysteine levels, however plasma homocysteine levels may increase in patients who receive general anesthesia with nitrous oxide for longer than 3 hours.

\section{References}

1. Homberger A, Linnebank M, Winter C, Willenbring H, Marquardt T, Harms E, Koch HG. Genomic structure and transcript variants of the human methylenetetrahydrofolate reductase gene. Eur J Hum Genet 2000; 8: 725-729.

2. Nagele P, Zeugswetter B, Wiener C, Burger H, Hupfl M, Mittlbock M, Fodinger M. Influence of methylenetetrahydrofolate reductase gene polymorphisms on homocysteine concentrations after nitrous oxide anesthesia. Anesthesiology 2008; 109: 36-43.

3. Shay H, Frumento FR, Bastien A. General anesthesia and methylenetetrahydrofolate reductase deficiency . J Anesth 2007; 21: 493-496.

4. Morgan GE, Mikhail MS. Klinik Anesteziyoloji (Tolunay M(Ed)). Günes Kitabevi, Ankara, 2004: 160 s.160-200.

5. Selzer RR, Rosenblatt DS, Laxova R, Hogan K. Adverse effect of nitrous oxide in a child with 5,10-methylenetetrahydrofolate reductase deficiency. N Engl J Med 2003; 349: 45-50.

6. Weimann J. Toxicity of nitrous oxide. Best Pract Res Clin Anaesthesiol 2003; 17: 47-61.

7. Goyette P, Rozen R. The thermolabile variant $677 \mathrm{C} \geq \mathrm{T}$ can further reduce activity when expressed in cis with severe mutations for human methylenetetrahydrofolate reductase. Hum Mutat 2000; 16: 132-138.

8. Blumenfeld Z, Brenner B. Thrombophilia-associated pregnancy wastage. Fertil Steril 1999; 72: 765-774.
9. Isotalo PA, Wells GA, Donnelly JG. Neonatal and fetal methylenetetrahydrofolate reductase genetic polymorphisms: an examination of C677T and A1298C mutations. Am J Hum Genet 2000; 67: 986-990.

10. Refsum H, Nurk E, Smith AD, Ueland PM, Gjesdal CG, Bjelland I, Tverdal A, Tell GS, Nygard O, Vollset SE. The Hordaland Homocysteine Study: a community-based study of homocysteine, its determinants, and associations with disease. J Nutr 2006; 136: 1731S-1740S.

11. Weisberg I, Tran P, Christensen B, Sibani S, Rozen R. A second genetic polymorphism in methylenetetrahydrofolate reductase (MTHFR) associated with decreased enzyme activity. Mol Genet Metab 1998; 64: 169-172.

12. Akar N, Akar E, Akcay R, Avcu F, Yalcin A, Cin S. Effect of methylenetetrahydrofolate reductase $677 \mathrm{C}-\mathrm{T}, 1298 \mathrm{~A}-\mathrm{C}$, and $1317 \mathrm{~T}-\mathrm{C}$ on factor V $1691 \mathrm{mu}-$ tation in Turkish deep vein thrombosis patients. Thromb Res 2000; 97: 163-167.

13. Dolek B, Eraslan S, Eroglu S, Kesim BE, Ulutin T, Yalciner A, Laleli YR, Gozukirmizi N. Molecular analysis of factor V Leiden, factor V Hong Kong, factor II G20210A, methylenetetrahydrofolate reductase C677T, and A1298C mutations related to Turkish thrombosis patients. Clin Appl Thromb Hemost 2007; 13: 435-438.

14. Yilmaz H, Isbir S, Agachan B, Ergen A, Farsak B, Isbir T. C677T mutation of methylenetetrahydrofolate reductase gene and serum homocysteine levels in Turkish patients with coronary artery disease. Cell Biochem Funct 2006; 24: 87-90.

15. Chiang PK, Gordon RK, Tal J, Zeng GC, Doctor BP, Pardhasaradhi K, McCann PP. S-Adenosylmethionine and methylation. FASEB J 1996; 10: $471-480$.

16. Amos RJ, Amess JA, Hinds CJ, Mollin DL. Incidence and pathogenesis of acute megaloblastic bone-marrow change in patients receiving intensive care. Lancet 1982; 2: 835-838.

17. Krajewski W, Kucharska M, Pilacik B, Fobker M, Stetkiewicz J, Nofer JR, Wronska-Nofer T. Impaired vitamin B12 metabolic status in healthcare workers occupationally exposed to nitrous oxide. Br J Anaesth 2007; 99: 812-818.

18. Royston BD, Nunn JF, Weinbren HK, Royston D, Cormack RS. Rate of inactivation of human and rodent hepatic methionine synthase by nitrous oxide. Anesthesiology 1988; 68: 213-216.

19. Badner NH, Beattie WS, Freeman D, Spence JD. Nitrous oxide-induced increased homocysteine concentrations are associated with increased postoperative myocardial ischemia in patients undergoing carotid endarterectomy. Anesth Analg 2000; 91: 1073-1079.

20. Badner NH, Freeman D, Spence JD. Preoperative oral B vitamins prevent nitrous oxide-induced postoperative plasma homocysteine increases. Anesth Analg 2001; 93: 1507-1510.

21. Lacassie HJ, Nazar C, Yonish B, Sandoval P, Muir HA, Mellado P. Reversible nitrous oxide myelopathy and a polymorphism in the gene encoding 5,10-methylenetetrahydrofolate reductase. Br J Anaesth 2006; 96: 222-225.

22. Myles PS, Chan MT, Kaye DM, McIlroy DR, Lau CW, Symons JA, Chen S. Effect of nitrous oxide anesthesia on plasma homocysteine and endothelial function. Anesthesiology 2008; 109: 657-663.

23. Frasca V, Riazzi BS, Matthews RG. In vitro inactivation of methionine synthase by nitrous oxide. J Biol Chem 1986; 261: 15823-15826.

24. Keating HJ, Kundrat M. Patient-controlled analgesia with nitrous oxide in cancer pain. J Pain Symptom Manage 1996; 11: 126-130.

25. Krauss B. Continuous-flow nitrous oxide: searching for the ideal procedural anxiolytic for toddlers. Ann Emerg Med 2001; 37: 61-62.

26. Luhmann JD, Kennedy RM, Porter FL, Miller JP, Jaffe DM. A randomized clinical trial of continuous-flow nitrous oxide and midazolam for sedation of young children during laceration repair. Ann Emerg Med 2001; 37: 20-27. 